\title{
Determination of the interannual variability of the Bering Strait transport from satellite data
}

\author{
T.J. Irwin, S. Martin and E. A. Munoz \\ School of Oceanography WB-10, University of Washington, Seattle, WA 98195, U.S.A.
}

\begin{abstract}
For the years 1980-88, we use satellite and meteorological data from the Chukchi and Laptev Seas to estimate the volume flux into the Chukchi Sea through the Bering Strait. We assume that the two seas have approximately the same amount of stored heat at the onset of freezing, then calculate the heat loss from both seas during the period from the onset of freezing to the formation of a solid ice cover. Because the Chukchi Sea generally takes 4-6 weeks longer to freeze over than the Laptev Sea, more heat is lost to the atmosphere from the Chukchi Sea than from the Laptev. On the assumption that the only source of this additional heat from the Chukchi is the Bering Strait inflow, and using published values for the mean temperature of the Bering Strait water, we calculate that the flow through the Bering Strait lies in the range of $0.5-1.5$ Sverdrups, which is comparable to values cited in the literature. This procedure suggests a technique for determination of the interannual variability of the Bering Strait inflow.
\end{abstract}

\section{INTRODUCTION}

Satellite-derived images of the Chukchi Sea for the period 1980-88 show interannual variability in the way in which the sea becomes ice-covered. This variability is attributable to changes in four quantities: atmospheric heat loss, heat stored in the sea at the onset of freezing, heat transport by ice advection, and heat transport through the Bering Strait. If we determine the first three quantities, we can calculate the Bering Strait transport.

Here we estimate heat storage in the Chukchi Sea from a comparison of the Chukchi and Laptev seas (Fig. 1). With the exception of the Bering Strait inflow, the Chukchi and Laptev seas are similar in character. For our purposes, the Chukchi Sea includes the region bounded by $66^{\circ}-74^{\circ} \mathrm{N}$ and $175-205^{\circ} \mathrm{E}$, and the Laptev Sea, the region bounded by $70-78^{\circ} \mathrm{N}$ and $110-145^{\circ} \mathrm{E}$. They both

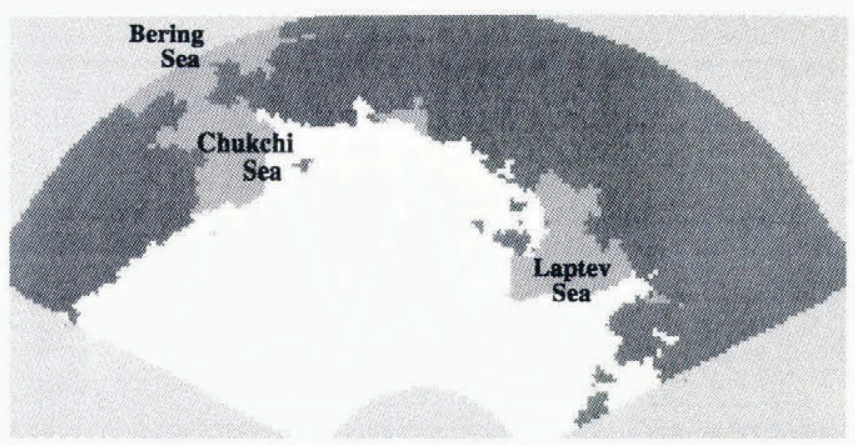

Fig. 1. A polar stereographic map of the ice extent for the Chukchi and Laptev Seas on 30 September 1980, as derived from FIC data. Land is represented by black, open water by dark gray, and ice by white. occur over their respective continental shelves at about the same latitude in the Arctic Ocean. In summer, the Yukon River water flows through the Bering Strait into the Chukchi Sea, and the Lena River flows into the Laptev. Both seas have depths of approximately $50 \mathrm{~m}$ and areas of about $700000 \mathrm{~km}^{2}$. The major difference between the two seas is that Bering Strait allows a transport of mass and heat from the North Pacific into the Chukchi Sea.

Historical satellite data show that in fall, the Chukchi Sea remains ice-free 4-6 weeks longer than the Laptev Sea (Parkinson and others, 1987). If we assume that each sea begins the freezing season with the same amount of stored heat, then we can determine the excess heat loss necessary to freeze over the Chukchi Sea. The data we use in this calculation consist of meteorological data from the National Meteorological Center (NMC) and sea-ice data from the Joint Ice Center (JIC). If we further assume that ice advection can be neglected, then based upon the excess heat loss, we can calculate the heat and volume flux through the Bering Strait.

\section{METHODS}

Our procedure is to use JIC data to determine the changes in ice extent and the NMC data to determine the total heat loss necessary to achieve freeze-up. The difference between the total heat extracted from the two seas is then used in combination with estimates of the mean temperature of the Bering Strait inflow to estimate the total transport and its interannual variability.

Figure 1 shows a map of ice extent for the western Arctic, derived from JIC sea-ice data. The JIC data are 


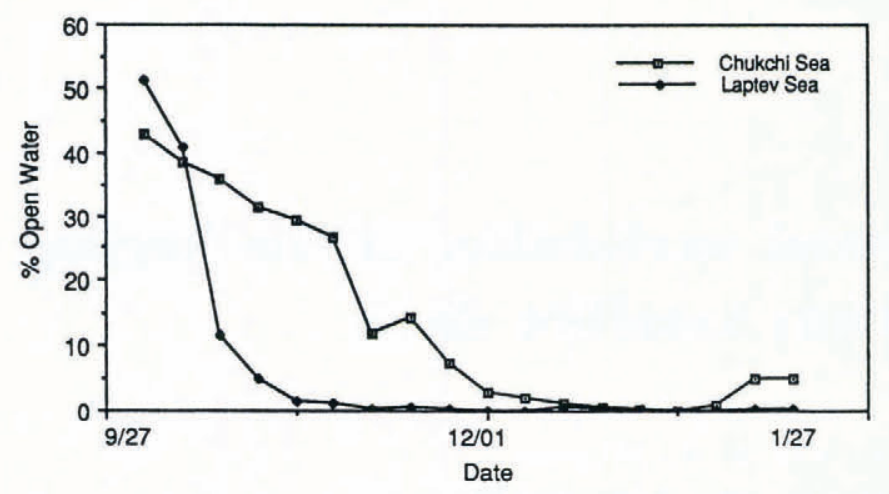

Fig. 2. The open water area in percent coverage versus time for the Chukchi and Laptev seas during fall and winter of 1980.

derived from AVHRR (Advanced Very High Resolution Radiometer) and SMMR (Scanning Multichannel Microwave Radiometer) combined with ground truth where available. The spatial resolution of the JIC data is approximately $28 \mathrm{~km} \times 15 \mathrm{~km}$; the temporal resolution is one week. Although this image shows ice extent only, the JIC data gives ice concentration at each grid point. From this data, we determined the rate at which each sea froze over. As an example, Figure 2 shows for the 1980-81 ice season, the decrease in the open water percent for each sea plotted at time intervals of one week. The values given in Figure 2 were calculated through summation of the open or partially open water areas in the two seas. The figure shows that in 1980, the Laptev Sea froze over earlier than the Chukchi. This phenomenon occurs for each of the nine years which we investigated.

For our nine-year study period, we calculated the open water heat loss for each sea using a bulk heat flux model. As input, the model uses the gridded air temperatures, surface pressures and relative humidities provided by NMC. Because of gaps in the humidity data, we took the mean of the relative humidities at halfmonthly intervals for the period 1978-87, then used this mean in our analysis. For the Chukchi Sea, the model also uses the mean monthly cloudiness data from Brower and others (1988). Because there is no equivalent data set for the Laptev Sea, we used the Chukchi cloudiness data set in the Laptev as well. The bulk heat flux model is described in Maykut (1978); a more recent version (Martin and others, 1992), uses the gridded data to parameterize sensible heat, latent heat, incoming shortwave radiation, emitted longwave radiation, and back radiation from clouds. Because the output from this model is gridded with a resolution of $380 \times 380 \mathrm{~km}$, these heat flux data were linearly interpolated with a standard twodimensional linear interpolation scheme to the same grid as the JIC ice concentration data. Given the limited availability of regional surface temperature data, the model derives the open water heat flux using default surface water temperatures of $-1.8^{\circ} \mathrm{C}$. We then sum the heat loss for each grid point over a one week period corresponding to the JIC ice data.

Because the JIC data gives only ice concentration, we assume that the ice is a perfect insulator, then use the ice concentration as a mask for the heat flux. At each grid

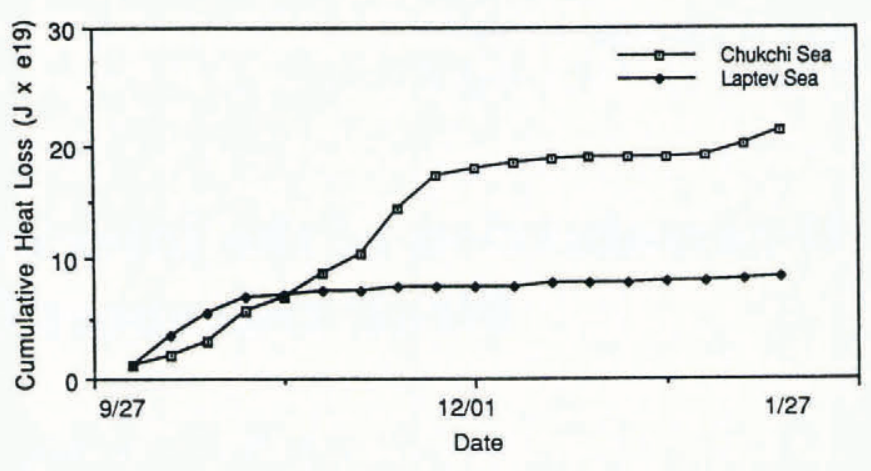

Fig. 3. Cumulative heat loss versus time for the Chukchi and Laptev seas during the fall and winter of 1980.

point for example, an ice concentration of $100 \%$ will mask the heat flux completely, while $50 \%$ ice concentration will mask half the heat flux, and so on. The result of this calculation is the weekly open water heat loss from the Chukchi and Laptev Seas. Using these data, we next calculate the cumulative and total heat loss from each sea. We define the cumulative sum as the sum of the weekly heat losses, beginning with the first week that the heat flux is from the ocean to atmosphere. The total heat loss is the sum of all heat losses through to the formation of a solid ice cover. Since we wish to compare directly the heat losses from both seas, we normalize the heat loss from the Laptev Sea as follows. At the beginning of the freezing season, the Chukchi Sea has an open water area Al, and the Laptev Sea has an open water area A2. We then multiply the heat loss from the Laptev Sea by the ratio A1/A2, so that the two seas appear to have the same initial open water area.

As an example, Figure 3 shows for 1980, the cumulative heat loss from the Chukchi and Laptev seas. Comparison of Figures 2 and 3 shows for each sea that the cumulative loss increases with time, then levels off to the total heat loss as the sea becomes ice-covered. Figure 3 also shows that at the end of freeze-up, the Chukchi Sea has a total heat loss which is about three times the Laptev Sea heat loss. The difference between the total losses is greater than the total loss from the Laptev. Figure 4 shows the yearly total losses for both seas. For each year of

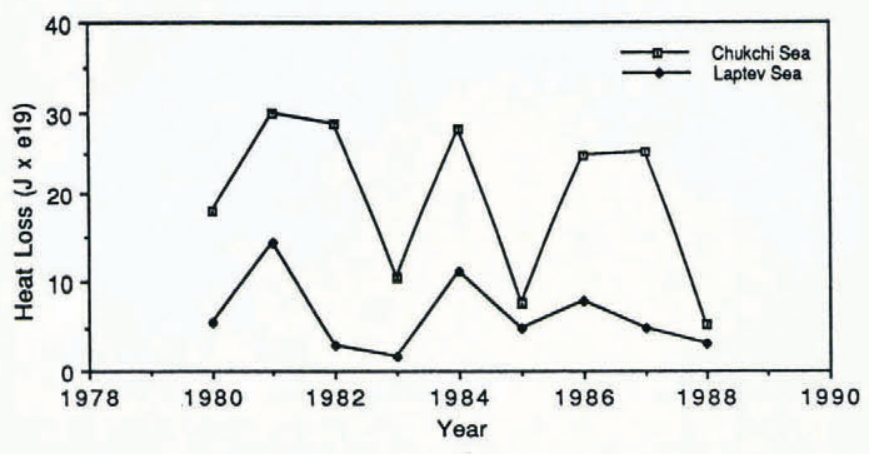

Fig. 4. The annual variability in the total heat loss necessary to freeze over the Chukchi and Laptev seas for the years $1980-88$. 
our study, the total heat loss from the Chukchi Sea was greater than that from the Laptev Sea. The heat loss between the two seas tends to be weakly correlated.

The difference in heat loss between the Chukchi and Laptev seas, or excess heat loss, arises from yearly differences in ice advection and in heat transport through the Bering Strait. In this calculation, our assumption about the ice cover is that once ice forms, the water under the ice is at freezing point, so that atmospheric cooling through the ice contributes only to ice growth, not to cooling of the water column. If ice advection into the open water region occurs, this ice is advected over a region of warm water, and the melting of this ice will cool this water independent of the atmospheric heat flux. Our calculations are such that if ice advances into our region, we will underestimate the heat loss necessary to cool the water, and if ice diverges from our region, we will overestimate the heat loss. The analysis of position data from buoys in and near the Chukchi and Laptev seas show that the mean annual ice speed in these regions is of order $2 \mathrm{~km} \mathrm{~d}^{-1}$ or $14 \mathrm{~km}$ per week (Colony and Thorndike, 1984). In the Chukchi Sea, the mean ice velocity is to the west; in the Laptev, it is to the northwest, so that the ice is slightly divergent in both cases. In contrast, for the Chukchi Sea, the edge of the open water region advances to the south with a characteristic velocity of $100 \mathrm{~km}$ per week; and for the Laptev, with a velocity of $125 \mathrm{~km}$ per week. Therefore, the mean ice advection speed is about $10 \%$ of the ice front speed. In summary, although ice advection may be important over short time periods, given that the mean advection velocity is at most $10 \%$ of the ice front velocity, we neglect ice advection.

Given the difference between the two curves in Figure 4 , and assuming that this heat is supplied only through the Bering Strait, we next estimate the mean autumnal transport through the strait. Table 1 lists for the years $1980-88$, the excess heat loss, the time in weeks for the Chukchi Sea to freeze over, and the derived Bering Strait transport in Sverdrups $\left(10^{6} \mathrm{~m}^{3} \mathrm{~s}^{-1}\right)$. The Bering Strait

Table 1. The excess heat required to freeze over the Chukchi Sea, the freeze-up time, and the derived transport through the Bering Strait for the period 1980-88

\begin{tabular}{cccc} 
Year & Excess heat loss & Freeze-up time & Transport \\
& $\times 10^{20} \mathrm{~J}$ & weeks & $\mathrm{Sv}$ \\
& & & \\
\hline & & & \\
1980 & 1.23 & 10 & 0.72 \\
1981 & 1.57 & 12 & 0.76 \\
1982 & 2.58 & 11 & 1.36 \\
1984 & 0.88 & 6.5 & 0.78 \\
1985 & 1.69 & 7 & 1.41 \\
1986 & 0.29 & 4 & 0.42 \\
1987 & 1.69 & 9 & 1.09 \\
1988 & 2.03 & 8 & 1.48 \\
& 0.21 & 6.5 & 0.19
\end{tabular}

transport was calculated as follows. First, from Coachman and others (1975, p. 49), we take the average temperature of the water entering the Chukchi Sea through the Bering Strait for the late fall and early winter to be $5^{\circ} \mathrm{C}$, and we assume that the freezing temperature of the Chukchi Sea water is $-1.8^{\circ} \mathrm{C}$. Second, we assume that the total excess heat transport occurs in the time interval between the onset and completion of freezing (column 3 in Table 1). The transport numbers listed in the last column of the table give the volume flux necessary to transport the excess heat in the time listed in the adjacent column. These transport numbers are consistent with published values for Bering Strait flow (Coachman and others, 1988).

\section{DISCUSSION AND SUGGESTIONS FOR FUTURE RESEARCH}

The above results show that comparison of the freeze-up of the two seas gives values of the Bering Strait transports which are on the order of $1 \mathrm{~Sv}$. The above analysis makes several simplifying assumptions. These include that the ice area for each sea increases only due to freezing so that ice advection is not important, and that ice is a perfect insulator. Although ice advection appears negligible when considering mean values, short term effects may be significant and should be included in further investigations. The ice insulation assumption is probably reasonable as a first approximation in that typical heat transport through $100-150 \mathrm{~cm}$ of ice is two orders of magnitude less than across an air/sea interface (Wettlaufer, 1991). We also lack realistic data as to the surface temperature distribution in both seas during freeze-up, and most important, there are very few data on the seawater temperature structure in the Bering Strait during freeze-up. Another possible effect which we ignore is the heat flux due to upwelling onto the shelf of the warm Atlantic layer, which could be a source of heat for both regions. Assumptions about the temperature of the Bering Strait water, which lead to Table 1, give a reasonable result. However, if we assume an average temperature of $2^{\circ} \mathrm{C}$, the volume flow through Bering Strait would have to double to transport the required heat. By obtaining accurate temperature profiles and introducing an ice advection model, this process should provide a reasonable estimate of the Bering Strait flow. In spite of these current shortcomings, we believe that this procedure shows promise and can be developed into a useful tool for determination of the Bering Strait transport.

\section{ACKNOWLEDGEMENTS}

The authors gratefully acknowledge the support of the Oceanic Processes Branch at NASA Headquarters, and the support of the Office of Naval Research under contract N00014-87-K-0160. We also thank the National Snow and Ice Data Center and Ms Claire Hansen for providing us with the Joint Ice Center data. This is contribution 1935 of the School of Oceanography, University of Washington. 


\section{REFERENCES}

Brower, W. A., R. G. Baldwin, C. N. Williams, J. L. Wise and L.D. Leslie. 1988. Climatic atlas of the outer continental shelf waters and coastal regions of Alaska. Volume III. Chukchi-Beaufort seas. Washington, DC, National Oceanic and Atmospheric Administration.

Coachman, L. K. and K. Aagaard. 1988. Transports through Bering Strait: annual and interannual variability. 7. Geophys. Res., 93(C12), 15,535-15,539.

Coachman, L. K., K. Aagaard and R. B. Tripp. 1975. Bering Strait: the regional physical oceanography. Seattle, WA, University of Washington Press.

Colony, R. and A. S. Thorndike. 1984. An estimate of the mean field of Arctic sea ice motion. 7. Geophys. Res., 89(C6), 10,623-10,629.
Martin, S., E. Munoz and R. Drucker. In press. The effect of severe storms on the ice cover of the northern Tatarskiy Strait. 7. Geophys. Res.

Maykut, G. A. 1978. Energy exchange over young sea ice in the central Arctic. 7. Geophys. Res., 83(C7), 3,6463,658 .

Parkinson, C. L., J. C. Comiso, H.J. Zwally, D.J. Cavalieri, P. Gloersen and W.J. Campbell. 1987. Arctic sea ice, 1973-1976: satellite passive-microwave observations. Washington, DC, National Aeronautics and Space Administration. (SP-489.)

Wettlaufer, J.S. 1991. Heat flux at the ice-ocean interface. 7. Geophys. Res., 96(D4), 7215-7236.

The accuracy of references in the text and in this list is the responsibility of the authors, to whom queries should be addressed. 